\title{
Non-DYT1 Early-Onset Primary Torsion Dystonia: Comparison with DYT1 Phenotype and Review of the Literature
}

\author{
Alfonso Fasano, MD, ${ }^{1}$ Nardo Nardocci, MD, ${ }^{2}$ Antonio Emanuele Elia, MD, ${ }^{1,2}$ Giovanna Zorzi, MD, ${ }^{2}$ \\ Anna Rita Bentivoglio, $\mathrm{MD}, \mathrm{PhD},{ }^{1}$ and Alberto Albanese, $\mathrm{MD}^{2,3 *}$ \\ ${ }^{1}$ Università Cattolica del Sacro Cuore, Roma, Italy \\ ${ }^{2}$ Istituto Nazionale Neurologico Carlo Besta, Milano, Italy \\ ${ }^{3}$ Università Cattolica del Sacro Cuore, Milano, Italy
}

\begin{abstract}
To investigate the clinical features of early-onset primary torsion dystonia (EO-PTD), 57 consecutive genetically characterized patients with onset before 21 years were studied. Sex, ethnic origin, family history of dystonia, age at onset, disease duration, site of dystonia onset and distribution at latest examination, dystonia progression, time to generalization, and motor disability were noted. The 14 patients $(25 \%)$ with GAG deletion (904_906/907_909delGAG) in the DYT1 gene were compared with the remaining non-DYT1 patients. Cranial involvement was present in $49 \%$ of non-DYT1 cases, but only $14 \%$ of DYT1 cases; non-DYT1 patients were younger at time of generalization. DYT1 cases had features similar to sporadic
\end{abstract}

non-DYT1 cases but differed markedly from familial nonDYT1 cases, the latter having later age at onset, less common limb onset, more frequent cervical involvement, and slower progression than DYT1 PTD. These findings indicate that nonDYT1 forms of EO-PTD differ clinically from those of DYT1 forms. Cranial involvement before 21 years of age is the strongest predictor of non-DYT1 status. Positive family history and cervical involvement are associated with less severe progression in non-DYT1 forms. (C) 2006 Movement Disorder Society

Key words: dystonia; genetics; DYT1; childhood onset; sporadic; familial
Primary torsion dystonia (PTD) is one of several disorders characterized by sustained muscle contractions usually producing body or limb twisting with abnormal postures or repetitive movements. ${ }^{1,2}$ Early-onset primary dystonia (EO-PTD) is the most severe form of PTD and often aggregates in families. ${ }^{3,4}$ Mutations in the DYTI gene are often responsible for EO-PTD; the most common defect being a GAG deletion in the coding region. ${ }^{5}$ The DYTl gene encodes torsinA, ${ }^{6}$ a protein of unclear function that interacts with endocellular membranes and may regulate vesicular exocytosis. ${ }^{7}$

This article includes Supplementary Video, available online at http:// www.interscience.wiley.com/jpages/0885-3185/suppmat

*Correspondence to: Prof. Alberto Albanese, Istituto Nazionale Neurologico Carlo Besta, Via G. Celoria, 11, 20133 Milano, Italy.

E-mail: alberto.albanese@unicatt.it

Received 27 July 2005; Revised 23 February 2006; Accepted 1 March 2006

Published online 13 June 2006 in Wiley InterScience (www. interscience.wiley.com). DOI: 10.1002/mds.21000
The common presentation of DYT1 PTD is limb onset with progressive generalization that spares cranial muscles, although it is increasingly recognized that DYT1 PTD is clinically heterogeneous. ${ }^{8}$ Although DYT1 gene defects are responsible for a large proportion of EOPTD, ${ }^{9}$ many, particularly non-Jewish cases, are not linked to the DYT1 gene. ${ }^{10}$

Information on non-DYT1 EO-PTD forms is scanty, but its phenotype partially overlaps with the DYT1 phenotype, raising the question as to whether specific clinical features are associated with the various genetically distinct forms. ${ }^{9,11}$ We investigated clinical features in 57 consecutive genetically characterized EO-PTD patients, seeking to better define non-DYT1 forms and identify systematic clinical differences between them and DYT1 forms.

\section{PATIENTS AND METHODS}

We recruited 57 consecutive patients (or probands in familial cases) diagnosed with EO-PTD at two Italian centers: Gemelli Hospital, Rome, and the Besta Neuro- 
logical Institute of Milan. All fulfilled the diagnostic criteria for definite PTD ${ }^{12}$ and in particular had symptoms onset before 21 years of age. ${ }^{13-15}$ Nonprimary dystonia was excluded from history (delivery, early postnatal life, development, etc.), clinical examination, brain magnetic resonance imaging, response to a 1-month trial of levodopa, and screening for metabolic diseases and other hereditary neurodegenerative syndromes. ${ }^{16}$ No patient had ataxia, Parkinsonism, eye movement deficits, or neuropathy. All were treated according to established therapeutic protocols with high-dose anticholinergics ${ }^{17}$ or baclofen. ${ }^{18}$ Follow-up evaluations were performed twice a year and included neurological examination, dystonia assessment, ${ }^{19}$ and video recordings (see Video, Segment 1).

The following were recorded for each patient: sex, ethnic origin, family history of dystonia, age of dystonia onset, site of dystonia onset, distribution at latest examination, and time to generalization. History of seizures, head or limb trauma, and febrile illness before or during disease course was also noted.

Dystonia severity and resulting disability were assessed using the Burke \& Fahn-Marsden dystonia rating scale, consisting of movement and disability subscales. ${ }^{19}$ Dystonia progression from onset site to other body areas was evaluated retrospectively, by ascertaining the mean number of body sites involved each year. Cases were considered familial when at least one first- or seconddegree family member was diagnosed with PTD by direct evaluation.

All patients gave written consent for DNA analysis. DNA was extracted from peripheral blood leukocytes by standard procedures. In all cases, the DYT1 gene was analyzed to detect $\mathrm{GAG}^{6}$ deletions (904_906/ 907_909delGAG; Glu 302/303del) and the 18-bp deletion (966_983del; Phe323_Tyr328del). ${ }^{20}$

\section{Statistical Analysis}

Continuous data were expressed as means $( \pm \mathrm{SD})$ and compared by one-way analysis of variance (ANOVA) and Student $t$ test. Pearson's correlation coefficient was used to assess relationships between continuous data. Dichotomous data were compared by $\chi^{2}$ test using the Fisher or the Yates corrections as appropriate. Disease progression was analyzed by repeated-measures ANOVA of the mean number of body areas progressively affected by dystonia during the disease course. Dystonia spread was assessed as the time from disease onset to involvement of two, three, and four body parts or generalization. Life table dystonia progression curves were compared using Gehan's Wilcoxon test. The likelihood of genotype prediction based on site of onset and specificity and sensitivity of each site of onset was determined. ${ }^{21}$

\section{RESULTS}

The series consisted of 18 women and 39 men. Mean age at onset was $9.1 \pm 4.2$ years (range, 2-18 years); mean disease duration was $17.9 \pm 12.1$ years (range, $1-55$ years). Mean age at most recent examination was $26.8 \pm 13.4$ years (range, $7-67$ years). At most recent examination, dystonia was generalized in 42 patients, segmental in 9 , focal in 5, and multifocal in 1 . A total of 45 patients had a sporadic form, and 12 were index cases of familiar forms in 12 unrelated families. No patient reported head or limb trauma, seizures, or severe febrile illness at onset or during follow-up.

\section{DYT1 Cases}

The DYT1 GAG deletion was found in 14 patients (25\%, 12 men, 2 women; ratio, 6:1), 13 of whom were Caucasian and $1 \mathrm{a}$ Sephardic Jew. The 18-bp deletion was not found. Mean age at onset was $10.1 \pm 3.7$ years (range, 6-18 years). There were 13 patients (93\%) who reported limb onset (lower in 6, upper in 7), and 1 had axial onset. Patients with upper limb onset had comparable onset age to those with lower limb onset.

At latest examination, mean disease duration was $24.0 \pm 13.5$ years (range, $1-55$ years); 13 (93\%) had generalized dystonia, involving oromandibular muscles in 3 cases and the larynx in 2 of these. In the only patient with axial onset, the condition had progressed to segmental dystonia (upper limb involvement) without generalization, after 19 years.

Age at generalization was $13.5 \pm 5.3$ years (range, 7-23 years); time from onset to generalization was $3.1 \pm$ 2.6 years (range, $1-10$ years). The rate of disease progression in upper limb-onset patients was similar that that in lower limb-onset patients. Symptom spread increased significantly with disease duration $(P<0.001$; Fig. 1).

All DYTI cases received anticholinergics titrated up to the maximum tolerated dose. Slight to moderate benefit was obtained in most cases. Baclofen was given as second-choice medication to patients who did not tolerate or did not benefit from anticholinergics.

\section{Non-DYT1 Cases}

In 43 patients (75\%, 27 men, 16 women; ratio, 1.7:1), a DYT1 mutation was not found. All except 1 of these was Caucasian, the other was a Sephardic Jew. Seven patients $(16 \%)$ had a family history of dystonia, 36 $(84 \%)$ were sporadic. Mean age at onset was $8.7 \pm 4.3$ years (range, 2-17 years). A total of 34 (79\%) had limb 


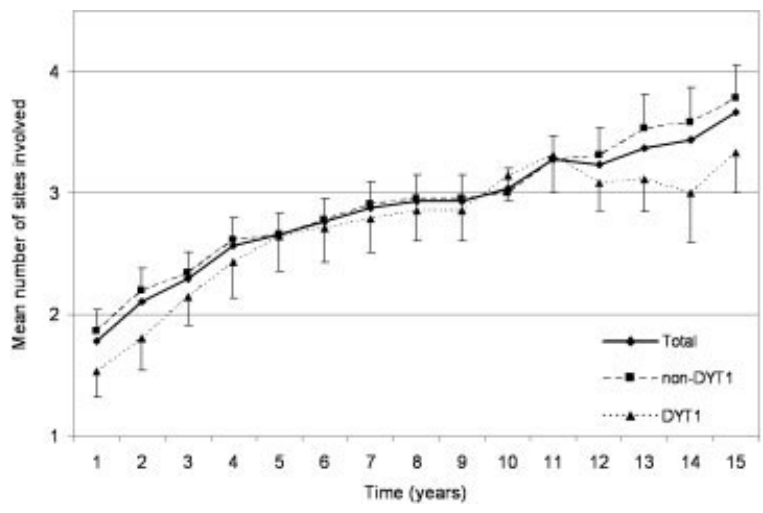

FIG. 1. Dystonia progression as assessed by increase in number of involved sites per year. There was no difference in progression between DYT1 $(n=14)$ and non-DYT1 patients $(n=43)$.

onset (lower limb in 16, upper limb in 18), 6 had cervical onset, 2 had axial onset, and 1 had oromandibular onset. Those with upper limb onset did not differ in age from those with lower limb onset, whereas limb-onset patients had earlier onset age than cervical-onset patients $(P=$ 0.005 cervical vs. lower limb; $P<0.05$ cervical vs. upper limb).

At latest examination, mean disease duration was $16.0 \pm 11.1$ years (range, 2-52 years); 29 (67\%) had generalized dystonia, with oromandibular involvement in $17(59 \%)$ of these and laryngeal involvement in 4 . One generalized case had laryngeal, but not oromandibular involvement. Dystonia was segmental in 8 (19\%), and multifocal in $1(2 \%)$. The dystonia remained focal (after $10.2 \pm 6.3$ years of disease) in $5(12 \%)$.

Patients with generalized dystonia had earlier onset than those without generalization $(7.1 \pm 3.6$ vs. $12.0 \pm$ 3.9; $P<0.001)$. Generalized dystonia occurred in $79 \%$ of patients with limb onset compared to only $22 \%$ without limb onset $(P<0.005)$; disease duration was comparable in the groups with and without limb onset.

Age at generalization was $9.2 \pm 4.0$ years (range, 4-20 years); time between onset and generalization was $2.2 \pm 1.5$ years (range, 1-7 years). Progression to a second body area occurred faster in patients with lower limb than upper limb onset $(P<0.05)$. By contrast, time to progression from second to third or subsequent site did not differ between upper limb- and lower limb-onset patients.

Non-DYT1 patients with sporadic dystonia had more rapid progression than those with familial occurrence. Times to involvement of a second, third, fourth site, and to generalization were much shorter in sporadic than in familial patients $(P<0.01, P=0.01, P=0.05, P=$ 0.05 , respectively), thus identifying 2 clinically distinct subgroups of non-DYT1 patients (Fig. 2). Non-DYT1 patients received the same therapeutic protocol as DYT1 patients, which, however, provided appreciable benefit in a few cases only.

\section{Familial non-DYT1 Cases}

The 7 familial non-DYT1 index cases consisted of 2 men and 5 women (ratio, 0.4:1). All were of Caucasian origin and belonged to 7 unrelated families. One patient was the proband of a well-characterized family with disease linked to the DYT13 locus. ${ }^{22}$ The prevalent phenotype was cervical district involvement with less frequent generalization than DYT1 and sporadic non-DYT1 forms, notwithstanding fealty to early onset age (13.9 \pm 2.0 years; range, $1-17$ years; generally later than other forms).

Cervical onset occurred in 3 of the 7 familial cases (43\%); limb onset occurred in the remaining 4 (two upper limb, two lower). At latest examinations (22.0 \pm $13.6 \mathrm{yr}$ after onset; range, 13-52 years) 3 of the familial non-DYT1 cases (43\%) had generalized dystonia. The cases without generalization ( 2 segmental and 1 focal) had cervical dystonia; 2 of these also had cranial involvement.

\section{Between-Group Comparisons}

DYT1 and non-DYT1 patients did not differ in terms of sex ratio, onset age, time to generalization, or proportion with laryngeal, cervical, and limb onset. Progression to second, third, and fourth site and generalization was also similar in both groups. By contrast, non-DYT1 patients more often had cranial involvement and earlier generalization $(P<0.01$ and $<0.05$, respectively, Table 1; Fig. 3). Analysis of the sensitivity and specificity of onset site for the diagnosis of DYT1 dystonia revealed

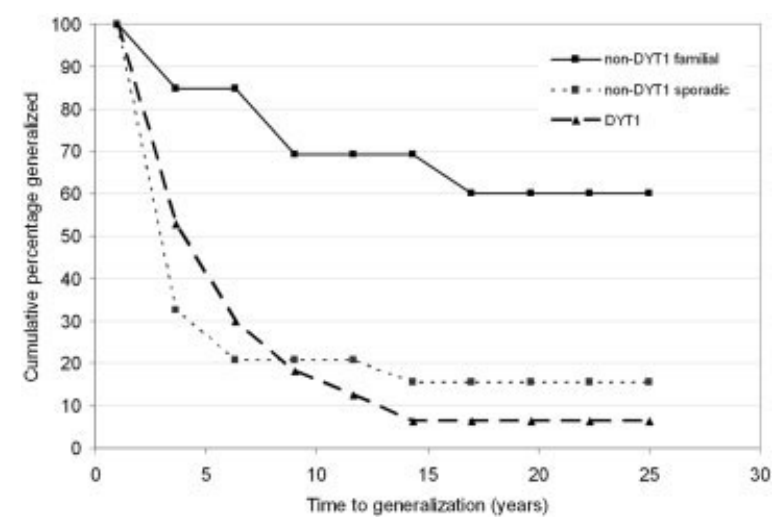

FIG. 2. Dystonia progression curves as assessed by time to generalized dystonia. Curves are shown for DYT1, familial non-DYT1, and sporadic non-DYT1 patients. Familial non-DYT1 patients had less severe progression than sporadic non-DYT1 patients and DYT1 patients $(P<0.05)$. 
TABLE 1. Clinical features in 14 DYT1 and 43 non-DYT1 cases of early-onset primary torsion dystonia

\begin{tabular}{|c|c|c|c|c|}
\hline & \multirow{2}{*}{$\begin{array}{c}D Y T 1 \\
\text { Total }\end{array}$} & \multicolumn{3}{|c|}{ Non- $D Y T 1$} \\
\hline & & Total & Sporadic & Familial \\
\hline Number & 14 & 43 & 36 & 7 \\
\hline M:F ratio & $7: 1$ & $1.7: 1$ & $2.3: 1$ & $0.4: 1^{\mathrm{a}}$ \\
\hline$\%$ of familial dystonia & 35.7 & 16.3 & 0 & 100 \\
\hline Mean age at onset (yr) & $10.1 \pm 3.7$ & $8.7 \pm 4.3$ & $7.7 \pm 3.9^{*}$ & $13.9 \pm 2.0^{\mathrm{a} *}$ \\
\hline Mean age at generalization (yr) & $13.5 \pm 5.3$ & $9.2 \pm 4.0^{\mathrm{b}}$ & $8.7 \pm 3.4^{\mathrm{b} *}$ & $17.5 \pm 3.5^{*}$ \\
\hline Mean time from onset to generalization $(\mathrm{yr})$ & $3.1 \pm 2.6$ & $2.2 \pm 1.7$ & $2.0 \pm 1.2$ & $4.0 \pm 4.2$ \\
\hline Mean disease duration (yr) & $24.0 \pm 13.5$ & $16.0 \pm 11.1^{\mathrm{a}}$ & $14.8 \pm 10.4^{\mathrm{b}}$ & $22.0 \pm 13.6$ \\
\hline$\%$ with of limb onset & 93 & 79 & 83 & $57^{\mathrm{a}}$ \\
\hline$\%$ with generalized dystonia & 93 & 67 & 72 & $43^{\mathrm{b}}$ \\
\hline$\%$ with cranial involvement & 14 & $49^{\mathrm{a}}$ & $53^{\mathrm{a}}$ & 30 \\
\hline$\%$ with laryngeal involvement & 14 & 9 & 11 & 0 \\
\hline$\%$ with cervical involvement & 0 & 14 & $6^{*}$ & $57^{\mathrm{b} *}$ \\
\hline
\end{tabular}

${ }^{\mathrm{a} D i f f e r e n t}$ from DYT1 patients $(P<0.05)$.

${ }^{\mathrm{b}}$ Different from DYT1 patients $(P<0.01)$.

*Different between sporadic and familial non-DYT1 patients $(P<0.005)$

no useful values. Both cranial and cervical onset were characterized by very low sensitivity $(6 \%)$ and specificity of approximately $70 \%$; limb onset had low sensitivity and low specificity. The likelihood of being a carrier of a mutation in the DYT1 gene was 1.4 in patients with limb onset and 0.2 in patients with onset not in a limb. With regard to upper and lower limb onset, we found that lower limb onset was more characteristic of DYT1 dystonia (likelihood ratio, 1.7), whereas upper limb onset had a likelihood ratio of 1; thus, a patient with arm onset had equal probabilities of having and of not having the DYT1 mutation.

DYT1 patients differed markedly from familial nonDYT1 cases. The latter had older age at onset and older

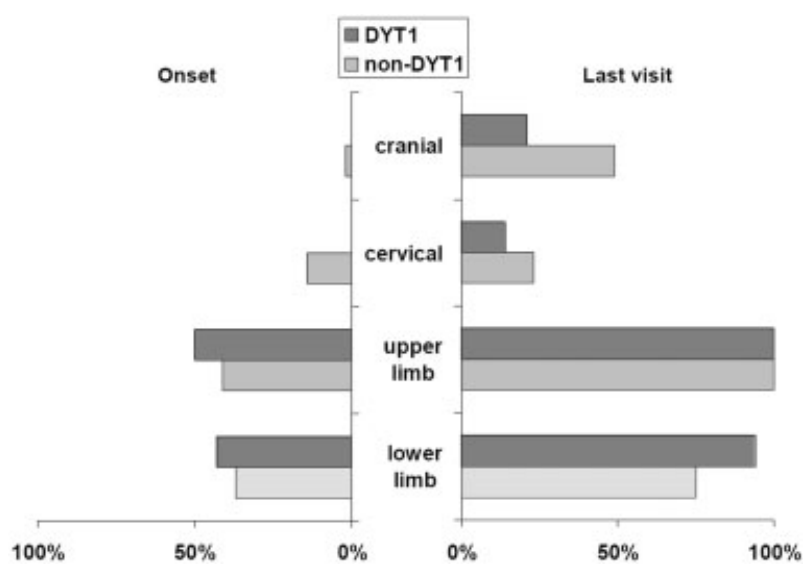

FIG. 3. Body sites affected at onset and during follow-up in 57 early-onset primary torsion dystonia (EO-PTD) patients (43 non-DYT1 and 14 DYT1). The histograms show the percentages of patients with cranial, cervical (including laryngeal), upper limb, and lower limb at onset (left) and who were affected in the same areas at most recent follow-up (right). age at generalization, more frequent cervical involvement and less common limb onset (Table 1).

Burke \& Fahn-Marsden scale disability scores were available for 44 patients (9 DYT1 and 35 non-DYT1). Mean disability scores at latest evaluation did not differ in these groups (DYT1 $8.9 \pm 7.3$; non-DYT1 $9.3 \pm 5.9$ ) and did not correlate with age at onset.

\section{DISCUSSION}

Early-onset PTD is progressive, usually resulting in severe disability ${ }^{3}$; clinical presentation is variable although limb onset occurs more often in DYT1 patients. The DYT1 form has been well studied, whereas the phenotype of EO-PTD in patients not carrying the DYT1 mutation is poorly known. Table 2 provides a synopsis of the non-DYT1 EO-PTD cases published so far. From Table 2, two main phenotypes are discernible: a mainly focal type with upper limb, cervical, or cranial involvement, and a so-called "mixed phenotype," 23 observed in DYT6, ${ }^{24}$ DYT13, ${ }^{22}$ and other reported cases.

Like previous studies, ${ }^{22,25-27}$ we found that cervical involvement occurred (inconstantly) in non-DYT1 cases. In our series, no DYT1 case had cervical involvement; such involvement is reported only rarely in DYT1 dystonia. ${ }^{9}$ These findings better characterize the extent of phenotypic overlap between DYT1 and non-DYT1 forms. We also found that non-DYT1 patients had a more heterogeneous phenotype than DYT1 cases. The typical phenotype in our DYT1 patients was limb onset and progression to generalized dystonia, whereas patients with cranial or cervical onset were unlikely to have the DYT1 mutation.

Cranial onset before 21 years had low sensitivity but high specificity for the exclusion of DYT1 dystonia, 
TABLE 2. Clinical features of published genetically unclassified cases of early-onset primary torsion dystonia

\begin{tabular}{|c|c|c|c|c|c|c|c|c|}
\hline $\begin{array}{l}\text { No. of patients } \\
\text { investigated }\end{array}$ & $\begin{array}{l}\text { Mean age } \\
\text { at onset } \\
(y r)\end{array}$ & Site of onset & Progression & $\begin{array}{l}\text { Cranial } \\
\text { involvement } \\
(\%)\end{array}$ & $\begin{array}{l}\text { Cervical } \\
\text { involvement } \\
(\%)\end{array}$ & Additional features & Pheno-type & Reference \\
\hline $\begin{array}{l}10 \text { of } 22 \text { affected } \\
\text { family } \\
\text { members } \\
\text { examined } *\end{array}$ & NA & $\begin{array}{l}\text { Larynx in } 7 \\
\text { Neck in } 2 \\
\text { Leg in } 1\end{array}$ & $\begin{array}{l}\text { Generalized in } 8 \\
\text { Segmental in } 1 \\
\text { Focal in } 1\end{array}$ & NA & NA & $\begin{array}{l}\text { Family with AD inheritance } \\
\text { (DYT4 dystonia) } \\
\text { Larynx involvement in } 9 \\
\text { patients } \\
2 \text { relatives with Wilson's } \\
\text { disease }\end{array}$ & MP & 37,38 \\
\hline 2 & 12.5 & $\begin{array}{l}\text { Neck in } 1 \\
\text { Arm in } 1\end{array}$ & Generalized in 2 & NA & NA & $\begin{array}{l}\text { Both familial cases } \\
\text { The only two generalized } \\
\text { cases of } 15 \text { early-onset } \\
\text { cases }\end{array}$ & & 29 \\
\hline 1 & 7 & Leg in 1 & Generalized in 1 & $100 \%$ & $100 \%$ & $\begin{array}{l}\text { Tongue involvement } \\
\text { Family with AD inheritance }\end{array}$ & MP & 39 \\
\hline 4 & 18.3 & $\begin{array}{l}\text { Eye in } 2 \\
\text { Larynx in } 1 \\
\text { Arm in } 1\end{array}$ & $\begin{array}{l}\text { Generalized in } 1 \\
\text { Multifocal in } 2 \\
\text { Focal in } 1\end{array}$ & $50 \%$ & NA & $\begin{array}{l}\text { Laryngeal involvement in } 2 \\
\text { patients } \\
\text { Family with } \mathrm{AD} \text { inheritance }\end{array}$ & MP & 27 \\
\hline $11 *$ & 12.5 & $\begin{array}{l}\text { Tongue: } 2 \\
\text { Larynx in } 1 \\
\text { Neck in } 3 \\
\text { Arm in } 4 \\
\text { Leg in } 1\end{array}$ & $\begin{array}{l}\text { Generalized in } 4 \\
\text { Segmental in } 7\end{array}$ & $73 \%$ & $64 \%$ & $\begin{array}{l}2 \text { families with AD } \\
\text { inheritance (DYT6 locus) } \\
\text { Frequent involvement of } \\
\text { larynx (in } 5 \text { cases) and } \\
\text { tongue (in } 3 \text { cases) }\end{array}$ & MP & 24,40 \\
\hline 4 & 12.3 & NA & $\begin{array}{l}\text { Generalized in } 1 \\
\text { Segmental in } 2 \\
\text { Focal in } 1\end{array}$ & NA & NA & $\begin{array}{l}\text { Cervical involvement in one } \\
\text { case with onset at } 8 \mathrm{yr}\end{array}$ & MP & 32 \\
\hline 2 & 6 & $\begin{array}{l}\text { Arm in } 1 \\
\text { Leg in } 1\end{array}$ & $\begin{array}{l}\text { Segmental in } 1 \\
\text { Focal in } 1\end{array}$ & $50 \%$ & NA & One case with anarthria & FP & 41 \\
\hline 7 & 13.6 & $\begin{array}{l}\text { Face in } 1 \\
\text { Neck in } 2 \\
\text { Arm in } 3 \\
\text { Leg in } 1\end{array}$ & $\begin{array}{l}\text { Generalized in } 3 \\
\text { Multifocal in } 1 \\
\text { Segmental in } 3\end{array}$ & $14 \%$ & $50 \%$ & $\begin{array}{l}3 \text { with family history (none } \\
\text { with generalization) } \\
1 \text { generalized case with } \\
\text { cervical involvement }\end{array}$ & MP & 42 \\
\hline 2 & 17 & $\begin{array}{l}\text { Eye in } 1 \\
\text { Neck in } 1\end{array}$ & $\begin{array}{l}\text { Segmental in } 1 \\
\text { Focal in } 1\end{array}$ & $50 \%$ & $50 \%$ & $\begin{array}{l}\text { Members of } 9 \text { families all } \\
\text { with AD inheritance }\end{array}$ & FP & 25 \\
\hline 6 & $<18$ & Arm in 6 & $\begin{array}{l}\text { Segmental in } 3 \\
\text { Focal in } 3\end{array}$ & No & $50 \%$ & $\begin{array}{l}\text { All writer's cramp } \\
\text { Two familial cases }\end{array}$ & FP & 43 \\
\hline 2 & 2 & Neck in 2 & Focal in 2 & No & $100 \%$ & $\begin{array}{l}\text { Identical twins (probably } \\
\text { AD inheritance) } \\
\text { Alcohol-responder } \\
\text { Brief tics }\end{array}$ & FP & 26 \\
\hline 35 & 15.4 & NA & $\begin{array}{l}\text { Generalized in } 11 \\
\text { Segmental in } \\
16 \\
\text { Focal in } 8\end{array}$ & NA & NA & & & 33 \\
\hline 25 & 7.7 & $\begin{array}{l}\text { Cranium in } 1 \\
\text { Neck in } 1 \\
\text { Arm in } 12 \\
\text { Trunk: } 2 \\
\text { Leg in } 9\end{array}$ & $\begin{array}{r}\text { Generalized in } 22 \\
\text { Segmental in } 3\end{array}$ & NA & NA & $\begin{array}{l}\text { Oromandibolar or laryngeal } \\
\text { dystonia in } 16 \text { patients }\end{array}$ & MP & 35 \\
\hline 2 & 20 & $\begin{array}{l}\text { Blepharo- } \\
\text { spasm in } \\
\text { Neck in } 1\end{array}$ & Focal in 2 & $50 \%$ & $50 \%$ & Family with $\mathrm{AD}$ inheritance & FP & 44 \\
\hline 3 & 4.7 & $\begin{array}{l}\text { Trunk in } 1 \\
\text { Leg in } 2\end{array}$ & Generalized in 3 & $100 \%$ & $100 \%$ & $\begin{array}{l}\text { Family with AR inheritance } \\
\text { (classified as DYT2 } \\
\text { dystonia) } \\
\text { Constant involvement of } \\
\text { tongue and larynx }\end{array}$ & MP & 45 \\
\hline 7 & 15.9 & $\begin{array}{l}\text { Eye in } 2 \\
\text { Neck in } 5\end{array}$ & Focal in 7 & $29 \%$ & $71 \%$ & $\begin{array}{l}33 \text { patients were affected } \\
\text { belonging to } 15 \text { families }\end{array}$ & FP & 46 \\
\hline 2 & $<18$ & Eye in 2 & Focal in 2 & $100 \%$ & No & $\begin{array}{l}\text { Members of } 2 \text { different } \\
\text { families with } \\
\text { blepharospasm AD } \\
\text { inherited }\end{array}$ & FP & 47 \\
\hline
\end{tabular}


TABLE 2. (Continued)

\begin{tabular}{|c|c|c|c|c|c|c|c|c|}
\hline $\begin{array}{l}\text { No. of patients } \\
\text { investigated }\end{array}$ & $\begin{array}{l}\text { Mean age } \\
\text { at onset } \\
(\mathrm{yr})\end{array}$ & Site of onset & Progression & $\begin{array}{c}\text { Cranial } \\
\text { involvement } \\
(\%)\end{array}$ & $\begin{array}{c}\text { Cervical } \\
\text { involvement } \\
(\%)\end{array}$ & Additional features & Pheno-type & Reference \\
\hline $\begin{array}{l}6 \text { of } 11 \text { affected } \\
\text { family } \\
\text { members }\end{array}$ & 10.7 & $\begin{array}{c}\text { Cranium in } 2 \\
\text { Neck in } 3 \\
\text { Arm in } 1\end{array}$ & $\begin{array}{l}\text { Generalized in } 2 \\
\text { Segmental in } 4\end{array}$ & $100 \%$ & $100 \%$ & $\begin{array}{l}\text { Family with AD inheritance } \\
\text { (DYT13 locus) }\end{array}$ & MP & 22 \\
\hline 2 & 5.5 & $\begin{array}{l}\text { Leg in } 1 \\
\text { Arm in } 1\end{array}$ & $\begin{array}{l}\text { Generalized in } 1 \\
\text { Segmental in } 1\end{array}$ & No & $100 \%$ & $\begin{array}{l}\text { AD inheritance } \\
\text { Myoclonus-dystonia } \\
\text { phenotype }\end{array}$ & & 48 \\
\hline 2 & 5 & Leg in 2 & Generalized in 2 & No & No & $\begin{array}{l}\text { Family with AR inheritance } \\
\text { (classified as DYT2 } \\
\text { dystonia) } \\
\text { Rapid progression } \\
\text { Fluctuations and } \\
\text { asymmetry of symptoms }\end{array}$ & & 49 \\
\hline $\begin{array}{l}1 \text { of } 4 \text { affected } \\
\text { family } \\
\text { members }\end{array}$ & 19 & Arm in 1 & Focal in 1 & No & No & $\begin{array}{l}\text { Family with AD inheritance } \\
\text { Scoliosis in } 6 / 10 \text { family } \\
\text { members examined }\end{array}$ & FP & 50 \\
\hline 7 & 14.3 & $\begin{array}{l}\text { Larynx in } 1 \\
\text { Neck in } 3 \\
\text { Leg in } 3\end{array}$ & $\begin{array}{l}\text { Generalized in } 3 \\
\text { Multifocal in } 1 \\
\text { Segmental in } 1 \\
\text { Focal in } 2\end{array}$ & No & $71 \%$ & $\begin{array}{l}\text { From } 5 \text { different families } \\
\text { all with AD inheritance } \\
\text { Laryngeal involvement in } 2 \\
\text { cases }\end{array}$ & MP & 51 \\
\hline
\end{tabular}

*The numbers of early-onset cases are unavailable.

AD, autosomal dominant; AR, autosomal recessive; FP, mainly focal phenotype; MP, "mixed phenotype," as described in text; NA, not available.

providing further evidence that DYT1 dystonia with cranial onset is uncommon. Limb onset had low sensitivity and low specificity for exclusion of DYT1 dystonia, indicating that limb onset is not uncommon in either DYT1 or non-DYT1 forms. When onset was in an upper limb, the probability of having DYT1 dystonia was equal to that of not having it; whereas when onset was in a lower limb, the probability of having DYT1 dystonia was greater.

The phenotype of DYT1 patients in the present series is consistent with previous observations. Mean age at onset was similar to the $9.9 \pm 4.3$ years reported for mainly British patients, ${ }^{28}$ and with the onset age of $12.5 \pm 8.2$ years found in Ashkenazi Jews. ${ }^{29}$ The majority of observed DYT1 cases (94\%) had limb onset, as is commonly observed in Ashkenazi Jews. ${ }^{29}$ Only one reported DYT1 case-a sporadic Japanese patient ${ }^{30}$ has been reported with axial onset. European series of non-Jewish DYT1 cases have generally been characterized by greater variation in presentation and dystonia distribution than Ashkenazi populations. ${ }^{11,31,32}$ Notwithstanding the variation in site of onset, progression to a generalized form is the norm in EO-DYT1 patients. ${ }^{9}$ This finding was also the case in our series, where all except one DYT1 patient progressed to generalization.

The present study indicates that the DYT1 mutation is not the most common cause of EO-PTD in Italy, with non-DYT1 cases three times more frequent that DYT1 cases. This finding is consistent with previous data, in which DYT1 cases formed $7.9 \%$ of the total in Serbia, ${ }^{33}$
$15 \%$ in Denmark, ${ }^{34}$ and $16 \%$ in Italy. ${ }^{35}$ By contrast, DYT1 patients accounted for $62 \%$ of early onset generalized cases in Russia. ${ }^{36}$ The higher prevalence of DYT1 cases in Russia and also in North America ${ }^{29}$ is probably related to the larger populations of Ashkenazi Jews in those countries.

To conclude, our study highlights some clear clinical differences between the various categories of EO-PTD. Sporadic non-DYT1 cases had the highest incidence of cranial involvement (much higher than in DYT1 patients). Except for this feature, however, the phenotype of sporadic non-DYT1 patients overlapped considerably with that of DYT1 cases. In keeping with this overlap, progression curves for sporadic non-DYT1 cases overlapped with those of DYT1 patients. Familial non-DYT1 cases also differed from sporadic non-DYT1 and DYT1 patients in that they progressed more slowly and had a relatively homogeneous phenotype, comparable to the "mixed phenotype"23 and characterized by cervical involvement, frequent nonlimb onset, and relatively benign disease course with uncommon generalization. This finding raises the possibility that other genetic defects are responsible for the dystonia in these familial cases. Pooling these cases for linkage analysis may reveal whether or not they are associated with a common locus, paving the way for investigations similar to those already performed on the DYT1 gene.

Acknowledgments: The authors thank E.M. Valente and B. Garavaglia for the genetic testing. This work was supported in 
part by Telethon grant E1165 to A.A. and by the Associazione Paolo Zorzi per le Neuroscienze to N.N.

\section{LEGEND TO THE VIDEO}

The videotape shows three early-onset primary torsion dystonia patients with limb onset and slow progression.

Patient 1: This patient had the GAG deletion in the DYT1 gene. He developed task-specific dystonia in the right lower limb at 9 years of age, which subsequently progressed to a generalized form. The first segment shows the patient at 11 years of age, 2 years after onset when all limbs are affected, with clumsiness of movements in the upper limbs and impaired gait, with outward rotation of the right lower limb. The second segment shows the patient at 14 years of age. Dystonia can also be observed at rest in the right lower limb; during attempted voluntary movement, there is abnormal extensor posture of leg and flexion of the right foot.

Patient 2: This is a sporadic non-DYT1 patient, who presented dystonia at 6 years of age. The right upper limb was affected first. The dystonia subsequently progressed without involving the lower limbs. The first segment shows the patient 6 months after onset. Action dystonia is evident in the right upper limb, left hand movements are clumsy, but the patient walks without difficulty. Segment 2 shows the patient at age 14; he has severe upper limb, cervical, and trunk dystonia. Remarkably, the lower limbs are spared.

Patient 3: Shown is a sporadic non-DYT1 patient who developed dystonia at 8 years if age. The disease started in the right upper limb and slowly spread to the contralateral upper limb, then mildly affected the trunk before stabilizing with no further progression. Segment 1 shows the patient at age 10: action dystonia of both upper limbs is obvious. Segment 2 shows the patient at age 16: severe dystonia occurs in both upper limbs and there is minimal trunk involvement.

\section{REFERENCES}

1. Fahn S, Marsden CD, Calne DB. Classification and investigation of dystonia. In: Marsden CD, Fahn S, editors. Movement Disorders 2. London: Butterworths; 1987. p 332-358.

2. Albanese A, Barnes MP, Bhatia KP, et al. A systematic review on the diagnosis and treatment of primary (idiopathic) dystonia and dystonia plus syndromes: report of an EFNS/MDS-ES Task Force. Eur J Neurol 2006;13:433-444.

3. Marsden CD, Harrison MJ, Bundey S. Natural history of idiopathic torsion dystonia. Adv Neurol 1976;14:177-187.

4. Bressman SB, de Leon D, Brin MF, et al. Idiopathic dystonia among Ashkenazi Jews: evidence for autosomal dominant inheritance. Ann Neurol 1989;26:612-620.

5. Ozelius L, Kramer PL, Moskowitz CB, et al. Human gene for torsion dystonia located on chromosome 9q32-q34. Neuron 1989 2:1427-1434.

6. Ozelius LJ, Hewett JW, Page CE, et al. The early-onset torsion dystonia gene (DYT1) encodes an ATP-binding protein. Nat Genet 1997; 17:40-48
7. Misbahuddin A, Placzek MR, Taanman JW, et al. Mutant torsinA, which causes early-onset primary torsion dystonia, is redistributed to membranous structures enriched in vesicular monoamine transporter in cultured human SH-SY5Y cells. Mov Disord 2005;20: 432-440.

8. Opal P, Tintner R, Jankovic J, et al. Intrafamilial phenotypic variability of the DYT1 dystonia: from asymptomatic TOR1A gene carrier status to dystonic storm. Mov Disord 2002;17:339345.

9. Bressman SB, Sabatti C, Raymond D, et al. The DYT1 phenotype and guidelines for diagnostic testing. Neurology 2000;54:17461752

10. Jarman PR, Del Grosso N, Valente EM, et al. Primary torsion dystonia: the search for genes is not over. J Neurol Neurosurg Psychiatry 1999;67:395-397.

11. Edwards M, Wood N, Bhatia K. Unusual phenotypes in DYT1 dystonia: a report of five cases and a review of the literature. Mov Disord 2003; 18:706-711.

12. Bressman SB, Raymond D, Wendt K, et al. Diagnostic criteria for dystonia in DYT1 families. Neurology 2002;59:1780-1782.

13. Fahn S, Bressman S, Marsden CD. Classification of dystonia. Adv Neurol 1998;78:1-10.

14. Bentivoglio AR, Elia AE, Filippini G, Valente EM, Fasano A, Albanese A. Clinical presentation and progression of sporadic and familial primary torsion dystonia in Italy. Adv Neurol 2004;94: 171-178.

15. Elia AE, Filippini G, Bentivoglio AR, Fasano A, Ialongo T, Albanese A. Onset and progression of primary torsion dystonia in sporadic and familial Italian cases. Eur J Neurol (in press).

16. Jankovic J, Fahn S. Dystonic disorders. In: Jankovic J, Tolosa E, editors. Parkinson's Disease and Movement Disorders. Baltimore: Williams and Wilkins; 2002. p 331-357.

17. Fahn S. High dosage anticholinergic therapy in dystonia. Neurology 1983;33:1255-1261.

18. Greene PE, Fahn S. Baclofen in the treatment of idiopathic dystonia in children. Mov Disord 1992;7:48-52.

19. Burke RE, Fahn S, Marsden CD, Bressman SB, Moskowitz C, Friedman J. Validity and reliability of a rating scale for the primary torsion dystonias. Neurology 1985;35:73-77.

20. Leung JC, Klein C, Friedman J, et al. Novel mutation in the TOR1A (DYT1) gene in atypical early onset dystonia and polymorphisms in dystonia and early onset parkinsonism. Neurogenetics 2001;3:133-143.

21. Sackett DL. Clinical Epidemiology: A Basic Science for Clinical Medicine. Boston: Little Brown; 1991.

22. Bentivoglio AR, Ialongo T, Contarino MF, Valente EM, Albanese A. Phenotypic characterization of DYT13 primary torsion dystonia. Mov Disord 2004;19:200-206.

23. Nemeth AH. The genetics of primary dystonias and related disorders. Brain 2002;125:695-721.

24. Almasy L, Bressman SB, Raymond D, et al. Idiopathic torsion dystonia linked to chromosome 8 in two Mennonite families. Ann Neurol 1997;42:670-673.

25. Munchau A, Valente EM, Davis MB, et al. A Yorkshire family with adult-onset cranio-cervical primary torsion dystonia. Mov Disord 2000;15:954-959.

26. Wunderlich S, Reiners K, Gasser T, Naumann M. Cervical dystonia in monozygotic twins: case report and review of the literature. Mov Disord 2001;16:714-718.

27. Holmgren G, Ozelius L, Forsgren L, et al. Adult onset idiopathic torsion dystonia is excluded from the DYT 1 region $(9 q 34)$ in a Swedish family. J Neurol Neurosurg Psychiatry 1995;59:178-181.

28. Valente EM, Warner TT, Jarman PR, et al. The role of DYT1 in primary torsion dystonia in Europe. Brain 1998;121:2335-2339.

29. Bressman SB, de Leon D, Kramer PL, et al. Dystonia in Ashkenazi Jews: clinical characterization of a founder mutation. Ann Neurol 1994;36:771-777.

30. Ikeuchi T, Shimohata T, Nakano R, Koide R, Takano H, Tsuji S A case of primary torsion dystonia in Japan with the 3-bp (GAG) 
deletion in the DYT1 gene with a unique clinical presentation Neurogenetics 1999;2:189-190.

31. Lebre AS, Durr A, Jedynak P, et al. DYT1 mutation in French families with idiopathic torsion dystonia. Brain 1999;122:41-45.

32. Leube B, Kessler KR, Ferbert A, et al. Phenotypic variability of the DYT1 mutation in German dystonia patients. Acta Neurol Scand 1999;99:248-251.

33. Major T, Svetel M, Romac S, Kostic VS. DYT1 mutation in primary torsion dystonia in a Serbian population. J Neurol 2001; 248:940-943.

34. Hjermind LE, Werdelin LM, Sorensen SA. Inherited and de novo mutations in sporadic cases of DYT1-dystonia. Eur J Hum Genet 2002;10:213-216.

35. Zorzi G, Garavaglia B, Invernizzi F, et al. Frequency of DYT1 mutation in early onset primary dystonia in Italian patients. Mov Disord 2002;17:407-408.

36. Slominsky PA, Markova ED, Shadrina MI, et al. A common 3-bp deletion in the DYT1 gene in Russian families with early- onset torsion dystonia. Hum Mutat 1999;14:269.

37. Ahmad F, Davis MB, Waddy HM, Oley CA, Marsden CD, Harding AE. Evidence for locus heterogeneity in autosomal dominant torsion dystonia. Genomics 1993;15:9-12.

38. Parker N. Hereditary whispering dysphonia. J Neurol Neurosurg Psychiatry 1985;48:218-224.

39. Bressman SB, Heiman GA, Nygaard TG, et al. A study of idiopathic torsion dystonia in a non-Jewish family: evidence for genetic heterogeneity. Neurology 1994;44:283-287.

40. Bressman SB, Hunt AL, Heiman GA, et al. Exclusion of the DYT1 locus in a non-Jewish family with early-onset dystonia. Mov Disord 1994;9:626-632.

41. Klein C, Friedman J, Bressman S, et al. Genetic testing for earlyonset torsion dystonia (DYT1): introduction of a simple screening method, experiences from testing of a large patient cohort, and ethical aspects. Genet Test 1999;3:323-328.

42. Kamm C, Castelon-Konkiewitz E, Naumann M, et al. GAG deletion in the DYT1 gene in early limb-onset idiopathic torsion dystonia in Germany. Mov Disord 1999;14:681-683.

43. Kamm C, Naumann M, Mueller J, et al. The DYT1 GAG deletion is infrequent in sporadic and familial writer' s cramp. Mov Disord 2000;15:1238-1241.

44. Brancati F, Defazio G, Caputo V, et al. Novel Italian family supports clinical and genetic heterogeneity of primary adult-onset torsion dystonia. Mov Disord 2002;17:392-397.

45. Khan NL, Wood NW, Bhatia KP. Autosomal recessive, DYT2-like primary torsion dystonia: a new family. Neurology 2003;61:18011803.

46. Maniak S, Sieberer M, Hagenah J, Klein C, Vieregge P. Focal and segmental primary dystonia in north-western Germany-a clinicogenetic study. Acta Neurol Scand 2003;107:228-232.

47. Defazio G, Brancati F, Valente EM, et al. Familial blepharospasm is inherited as an autosomal dominant trait and relates to a novel unassigned gene. Mov Disord 2003;18:207-212.

48. Kock N, Kasten M, Schule B, et al. Clinical and genetic features of myoclonus-dystonia in 3 cases: a video presentation. Mov Disord 2004; 19:231-234

49. Moretti P, Hedera P, Wald J, Fink J. Autosomal recessive primary generalized dystonia in two siblings from a consanguineous family. Mov Disord 2005;20:245-247.

50. O'Riordan S, Lynch T, Hutchinson M. Familial adolescent-onset scoliosis and later segmental dystonia in an Irish family. J Neurol 2004;251:845-848.

51. O'Riordan S, Raymond D, Lynch T, et al. Age at onset as a factor in determining the phenotype of primary torsion dystonia. Neurology 2004;63:1423-1426. 